\title{
ISLAM NUSANTARA: PREJUDICE AND SOCIAL CONFLICT
}

\author{
Reza Fahmi ${ }^{1}$ and Prima Aswirna ${ }^{2}$ \\ ${ }^{1}$ UIN Imam Bonjol, Padang, rezafahmi@uinib.ac.id \\ ${ }^{2}$ UIN Imam Bonjol, Padang, primaaswirna@uinib.ac.id
}

\begin{abstract}
This research is based on the fact that there are religious leaders and some people who oppose the idea of Islam Nusantara. When the religious figure represented a formal legal institution (MUI), it had a significant influence on the views of the people of Padang. Therefore, the polemic of Islam Nusantara gives its own style about the existence of Islam Nusantara in the land of Minang. Further research objectives: (1) Describe the prejudices of community leaders about Islam Nusantara. (2) Describe the picture of people's prejudices about Islam Nusantara. (3) Connecting the prejudices of religious leaders and the community and its relation to the social conflict of the people of Padang City. The study uses qualitative approaches and quantitative mixing methods (mixed method). The population in this study were 32 religious leaders and 168 community members. Data collection techniques using; observation, interview and psychological scale. The sampling technique is random sampling technique. Data analysis techniques using Pearson correlation (Pearson correlation). The results of this study found that generally the negative prejudices of religious leaders about Islam Nusantara were high. While social conflict in the midst of society is classified as low. Whereas the correlation aspect shows that there is no relationship between community's prejudices about Islam Nusantara and social conflict in the midst of society.
\end{abstract}

Keywords: Community Leaders, Community Members, Islam Nusantara and Social Conflict.

Abstrak. Penelitian ini berdasarkan fakta bahwa ada tokoh agama dan sebagaian masyarakat yang menentang pemikiran tentang Islam Nusantara. Ketika tokoh agama tadi mewakili lembaga legal formal (MUI) maka, ianya memberikan pengaruh yang signifikan terhadap pandangan masyarakat kota Padang. Oleh karenanya polemik Islam Nusantara memberikan corak tersendiri tentang keberadaan Islam Nusantara di Ranah Minang. Lebih jauh tujuan penelitian : (1) 
Menggambarkan Prasangka tokoh masyarakat tentang Islam Nusantara. (2) Menggambarkan gambaran Prasangka masyarakat tentang Islam Nusantara. (3) Menghubungkan antara prasangka tokoh agama dan masyarakat serta kaitannya dengan konfik sosial masyarakat kota Padang. Penelitian menggunakan pendekatan kualitatif dan kuantitatif mixing methods (metode campuran). Populasi dalam penelitian ini sebanyak 32 orang tokoh agama dan 168 orang anggta masyarakat. Teknik pengumpulan data dengan menggunakan; observasi, wawancara dan skala psikologi. Teknik penarikan sampel dengan acak sederhana atau simple random sampling. Teknik analisa data dengan menggunakan korelasi pearson (pearson correlation). Hasil penelitian ini mendapati umumnya Prasangka negatif tokoh agama tentang Islam Nusantara tergolong tinggi. Sedangkan konflik sosial ditengah-tengah masyarakat tergolong rendah. Sedangkan pada aspek korelasi diperoleh hasil bahwa, tidak ada kaitan antara prasangka masyarakat tentang Islam Nusantara tidak berkorelasi dengan konflik sosial ditengah-tengah masyarakat.

Kata Kunci : Tokoh Masyarakat, Anggota Masyarakat, Islam Nusantara dan Konflik Sosial.

\section{Introduction}

The Presence of Islam Nusantara, with its pros and cons, rated as a revival of the identity of Indonesian nationalism in the face of a wave of Transnational Islamic movements in recent years. Although criticism of the transnational movement has been expressed by Abdurrahman Wahid in many of his essays, but until now the Islamic characteristic which mixed with the Arabic characteristic actually found its momentum, not only politically but also culturally. Mark R. Woodward explained that the transnational movement had been going on for a long time, and Islam was part of the transnational movement at the beginning of its presence in the archipelago. The Arizona State University Professor said of his experience when researching Javanese Islam in Yogyakarta since 1978. Mark clarified that his research should not be generalized as Javanese Islam, due to the fact that the research was only carried out in a small village located within the fortress of the Yogyakarta Palace. He realized that Javanese Islam had a very broad understanding because of 
the variety and richness of Javanese culture both in Central Java, West Java and East Java. He explained that the community he had met at that time was a Javanese society that made Islam an identity, but most of the Islamic rituals were not lived, except for matters relating to the Javanese tradition that were still highly considered. Mark narrated that most of these people are below the poverty line. In general, they hardly carry out the prayers, fasting, and cannot even read the Qur'an, even though it is only a letter of Fatihah. The community is very fond of pilgrimage to the shrine which is considered sacred, likes and believes in talismans, keris, rings, and making wayang (Javanese traditional puppet) a part of daily life. Nevertheless, Islam remains as a part of identity. At the birth and death ceremony, the community invited students from Kampung Kauman located near the village. This community relationship with the Kauman community is almost without conflict, so Mark called it a symbiotic relationship.

This society is developing. There is a mosque that is managed by the Muhammadiyah religious organization. In this mosque, they gave lectures specifically on the theme of purification in which all activities of the Kejawen were considered as forms of syirik, but at the same time Muhammadiyah also opened educational institutions and health services for the surrounding community. This community sends their children to study at Muhammadiyah schools, therefore some of these communities start to pray and fast more diligently than before and even some of them go on hajj. However, that does not mean that their Javanese tradition is reduced or even stopped. This society does not see their Kejawen and Islam as a contradiction.

According to Mark, there are two factors that influence this society so there is no conflict with the Javanese and Islamic traditions as identity. First, in the political condition of Islam in Indonesia the presence of Muhammadiyah and Nahdhatul Ulama (NU) in this context actually helps the community to identify themselves as "I am Muslim but not like Muhammadiyah or NU". Second, the boundaries of Javanese 
identity and Islam are also increasingly unclear. This transformation took place quickly, so that some of the noble children of this community despite studying in a Dutch school, but when married they still invited Kauman students and they even perform the hajj.

From this research study, it can be illustrated that Islam that came at that time as a "santrification" process was part of Transnational Islam, present and meeting with Javanese tradition where most of these traditional beliefs were considered syirik. Even though santrification is able to influence Javanese society, it does not mean that Javanese tradition is lost. Instead Islam experiences 'adaptation' and transformation in such a way. This is what convinced Mark that the transnational movement would not succeed in Indonesia, until the time they were able to transform and adapt to local culture. Therefore, Mark emphasizes the focus of research on local Muslim wisdom in Indonesia to enrich Islam Nusantara, not only Islam in Java but also Islam in other part of Indonesia.

However, the rejection of Islam Nusantara in West Sumatra in general and the city of Padang in particular, was initiated by the statement of the Chairperson of the West Sumatra MUI who clearly rejected the Islam Nusantara, specifically he stated "We are the West Sumatra MUI and the West Sumatra City / Regency MUI stated without any doubt that: 'Islam Nusantara' in any concept or definition is not needed in the realm of Minang (West Sumatra). For us, the name 'Islam' is perfect and does not need to be added to any appendage, "concludes the West Sumatra MUI as documented and uploaded in the Facebook account of the Chairperson of West Sumatra MUI, Buya Gusrizal Gazaha, on July $23^{\text {rd }}, 2018$, as quoted by AFP on Wednesday (7/25/2018). There are four reasons of West Sumatra MUI's rejection; the possibility of creating mass confusion about Islam Nusantara, narrowing the meaning of universal Islam, only focusing in tolerance as one aspect of Islam, and possibility to divide Muslims and negative views from Muslims in other regions. 
As the reponse, West Sumatra Nahdlatul Ulama (PW-NU) Regional Leaders have invited the West Sumatra Indonesian Ulama Council to negotiate. But until now it has not been responded by the West Sumatra MUI.

Departing from the pros and cons of the statement of the representative of the formal Islamic institutions (MUI) of West Sumatra, it is suspected that it is related to the potential for social conflict in the midst of society. Especially to the people of Padang and West Sumatra who support the rejection of Islam Nusantara with the community that supports Islam Nusantara. This is the background of the research that interest the team in studying social prejudice allegedly related to social conflict.

\section{Identification of Problems}

Islam Nusantara polemic, which has also been widely criticized on social media, is the reading of the Qur'an in the Javanese style at the Commemoration of Isra 'Mi'raj at the State Palace, and continued with the program "Koran of Javanese Style of the Qur'an \& Indigenous Islam", which organized by GUSDURian, at the LKiS Foundation Padepokan in Sorowajan (Wednesday, 05/27/2015). According to the cons, reading the Qur'an with Javanese style is an act of syncretism, which is prohibited in religion, because it mixes the teachings of Islam with the teachings of nonMuslims. Meanwhile, supporters of the government, said the Islam Nusantara discourse is the idea of acculturation. Certain values in Islam are "adjusted" to the culture of the Nusantara which is permissible in religion. The reason is, when Islam came to Indonesia, there was already another culture that developed in the archipelago. Therefore, this culture must not be eliminated. Islam Nusantara is a distinctive Islam with a variety of cultural accessories that are different from the culture of the Arabian Peninsula.

Those who cons, has a different argument. They believe that Islam is a teaching that is whole, perfect, and pure. They also believe that there is no added culture in 
Islamic teaching, because it will tarnish the purity of Islamic teachings. In their principle, syncretism has no place. Purification of faith is absolute. Among the pros and cons, there is a third group, which believes that the definition of Jokowi's Islam Nusantara is unclear. In general, interpreted as a tolerant Islam, in this case, only read as Javanese Islam. That makes Islam Nusantara branded as syncretic, because of its acceptance of Javanese cultural elements, which are thick with the teachings of Hinduism and Buddhism.

The debate between the pros and cons of Islam Nusantara, expanded on social media. NU as the initiator of the Islamic Nusantara idea, continued to socialize the $\mathrm{NU}$ version of the Islam Nusantara ideas, especially on the $\mathrm{NU}$ official website. Fighting with NU's Islam Nusantara discourse, is HTI. HTI took a counter position against the practice of Jokowi's Islam Nusantara rhetoric (government version), because of the controversy with the Islamic values they understood. Therefore, HTI also made a number of rhetoric, why reject Islam Nusantara. There was a rhetorical debate against Islam Nusantara between NU and HTI, where NU represented the Jokowi's version of the Islam Nusantara model. The rhetorical debate is interesting to study. How NU and HTI use the rhetorical situation to build the Islamic version of the discourse of the archipelago of each organization. Islam Nusantara is an understanding rooted in local culture (local wisdom), however acceptance in the form of support for its existence is also a reality in the community. Even so the existence of rejection of its existence is also an inseparable part. So this becomes an interesting problem to be studied more deeply. Considering the rejection supported by the fatwa of Ulama or mass organization support has the potential for social conflict which would certainly harm the Indonesian people in general and Muslims in particular. 


\section{Research Problems}

The facts above show that there are differences in the perspectives of Islamic organizations and even community leaders (including religious leaders or Ulama) in interpreting Islam Nusantara. But the realm of Islamic culture in the Nusantara is also not studied in a long time, there is diversity in the understanding and practice of doctrines or socio-cultural expressions of Muslims. This difference is related a lot to the cultural character of ethnic groups which is also very diverse. Therefore, the expression of Islamic Acehnese for example contains certain differences with Islamic expressions of Javanese or Sundanese and so on. This difference was also evident in the post-World War II period when the Southeast Asia region achieved independence. Differences between countries are mainly related to the mode of relations between Islam and the state. In Malaysia and Brunei Darussalam, for example, Islam is the official state religion. Whereas in Indonesia, even though Muslims are the absolute majority, Islam does not form the basis of the state or the official religion of the state. Muslims are a minority in Singapore, Thailand and the Philippines; in the last two countries Muslims have had confrontations with the central government in Bangkok and Manila.

However the problems of this research are:(1) What is the history of the development of Islam in the archipelago? (2) What are the categories of prejudice of community leaders and community members about Islam Nusantara? (3) Is there a relationship between prejudice of religious leaders and community members about Islam Nusantara with social conflict amongst the people, in connection with Islam Nusantara?

\section{Methodology}

The study used qualitative approaches and quantitative mixing methods (mixed methods). The population in this study were 32 religious leaders and 
168 community members. Data collection techniques using; observation, interview and psychological scale. A simple random sampling technique. Data analysis techniques using Pearson correlation.

\section{Results and Discussion}

The spread of Islam was a very important process in Indonesian history, but also the most abstract. When, why, how the Indonesian population began to embrace Islam was debated by some scientists, but no definitive conclusion was possible. Generally there are two possibilities for the process of entry of Islam into the archipelago. First, as said by Prof. Hamka - by pointing to one of them in the news notes of Chinese travelers, as outlined in the Minutes of the Seminar on the Entry of Islam into Indonesia in Medan in 1963 states that Islam entered the Archipelago (Indonesia) in the first centuries of the Hijriyah or in the centuries seventh or eighth. ${ }^{1}$

This statement is evidenced by Chinese news records that on the island of Java in the seventh century AD stood a Hindu Holing kingdom (Kalingga) ruled by a Shima queen. According to the news, the existence of this kingdom was heard by King TaChih who then sent a messenger to the kingdom. Ta-chih is an Arabic designation given by the Chinese. As mentioned above, that in about the seventh century or eighth AD the traders from the Persian Gulf (Arabic) in the west to Southeast Asia and China in the east. Because the Persian Gulf, India (Gujarat) regions were earlier controlled by Muslims and it is certain that most of the traders were Muslims. ${ }^{2}$ Thus the strong suspicion is that in the seventh or eighth century AD many Muslim Arabs met Javanese and Sumatran people.

\footnotetext{
${ }^{1}$ See Hamka's Principles (Main Comparison of MD Mansur's Target), Masuk dan Berkembangnya Agama Islam di daerah Pesisir Sumatera Utara, in "Risalah Seminar Masuknya Islam ke Indonesia tahun 1963 di Medan". (Medan: Committee for the History of History of the Entry of Islam into Indonesia), 72. See Ahwan Mukarrom, Sejarah Islamisasi Nusantara (Surabaya: Jauhar, 2009), 58.

${ }^{2}$ Ahwan Mukarrom, Sejarah Islamisasi Nusantara (Surabaya: Jauhar, 2009), 58.
} 
The second opinion states that Islam entered Indonesia in the 11th century AD with evidence of the grave of a woman in Leran about eight kilometers south of the town of Gresik, East Java. ${ }^{3}$ From observations of the year on the gravestone, it was concluded that Fatimah bint Maymun the woman who was buried died in 1082 AD. By looking at the number of the year, it can be said that Fatimah bint Maymun had entered this region during the period of the Dhaha Kediri kingdom. The difference in opinion of the researchers also concerns the time of the arrival of Islam to the archipelago. Some researchers claim that Islam came to the archipelago in the 1st century Hijriyah or 7th century AD, as believed by Naquib al-Attas, Fatimi, and Uka Tjandrasasmita that Islam began to develop rapidly in the 8th century AD. While others believe that Islam came in the 13th century AD. However, this theory received many objections from many researchers who indicated that the 13th century AD was a time of development and expansion of Islam to various regions of the archipelago. As a synthesis it can be said that Islam came to the archipelago in the 7th century AD which was marked by the establishment of Muslim villages in the 2nd century Hijriyah or the 8th century AD and expanded widely in the 13th century AD. ${ }^{4}$ West, Banten and Makassar. Islam that spreads in these areas is said to be pure. Furthermore, regarding the area that became the first destination of Islam. There are two regions which were first influenced by Islam, namely the Sumatra region which is the path of international trade, and Java. Initially, Islam was influential in areas not controlled by Hindu-Buddhism, such as Aceh, Sumatra acculturated with local traditions. Meanwhile, Islam that came to Java actually coincided with the heyday of the Hindu-Buddhist kingdom. Therefore Islam in Java is syncretistic. ${ }^{5}$

\footnotetext{
${ }^{3}$ Hasan Muarif Ambary, Menemukan Peradaban Jejak Arkeologis dan Historis Islam Indonesia (Ciputat: PT. Logos Wacana Ilmu 2001), 54.

${ }^{4}$ Azhar Arsyad, Islam Masuk dan Berkembang di Nusantara secara Damai, in Komaruddin Hidayat, Menjadi Indonesia: 13 Abad Eksistensi Islam di Bumi Nusantara (Bandung: Mizan, 2006), 76.

${ }^{5}$ Fauzan Saleh, Teologi Pembaharuan: Pergeseran Wacana Islam Sunni di Indonesia Abad XX (Jakarta: Serambi, 2004), 40.
} 
Qualitative Analysis Results

Qualitative analysis is used to examine the existence of Islam in the archipelago that has interacted intensively, between local cultural values and norms with Islam as a guide for the life of the people of the city of Padang.

Facts of Islamic History in the Archipelago

As is the case with the above problem, differences of opinion from researchers also occur on the issue of Islamic identity which first entered and was influential in the archipelago ${ }^{6}$ if seen from the strong influence, Sufism occupies an important position in the process of Islamization in the archipelago, although it is still doubted by some researchers. The argument of the researchers who hold on Sufism is on the aspect of Islamic flexibility, the attitude of compromise with tradition. An aspect of Islam that is difficult to find in the Islamic legal tradition (Fiqh) both legal practices related to worldly issues and the issue of ukhrowi, whether originating from native Indonesian religion (Animism and Dynamism) or Hindu-Buddhist traditions. ${ }^{7}$ The last opinion seems to be closer to the truth. Because, Islam entered the archipelago when the position of Islam and Muslims in the Middle East suffered a setback due to the fall of Baghdad at the hands of the Mongol rulers in $1258 .{ }^{8}$ In this era of Islamic decline, Muslim scientists turned more to the discipline of Sufism, thus making Sufism more dominant in the horizons of Islamic thought.

Talking about the Archipelago and Indonesia which are both briefly refer to one region, but in different situations and conditions. "Nusantara" represents the

\footnotetext{
${ }^{6}$ See Ricklefs, Modern Indonesian History, trans. Dharmono Hardjowidjono (Yogyakarta: Gadjah Mada University Press, 2007), 18.

${ }^{7}$ Delear Noer, Gerakan Modern Islam di Indonesia (Jakarta: LP3ES, 1996), 21.

${ }^{8}$ Karel A. Steenbrink, Beberapa Aspek tentang Islam di Indonesia Abad ke-19 (Jakarta: Bulan Bintang, 1984), 4.
} 
name of the early days of the existence of the region that is now called Indonesia. Nusantara comes from two words Nusa and Antara. Nusa means island or homeland, while Antara means distance, between, lapses, in the middle of two objects. These two words are then combined by removing the letter "a" in the word "Antara", thus becoming Nusantara. ${ }^{9}$ With this understanding, the archipelago means the islands located between two, precisely between the two continents, Asia and Australia.

The influence of Islam in communities on the north coast of the island of Java is more prominent compared to the population of Java on the south coast. This shows that trade relations on the island of Java were quite crowded at the time, so that Islam was more pervasive, whereas in the southern part of Java the cultural contact was very rare, so the influence of Islam was less profound. This is evidenced by the Kraton of Yogyakarta and Solo, which is located in the southern part of the island of Java, which still survives with Javanese culture, proving that cultural contact provides a great opportunity for cultural influence. On the other hand on the north coast has been heavily influenced by Wali Songo.

It is also impossible for Islam and its religious formations to force themselves to reject the culture in the archipelago. The important role of Islamic history at the beginning of its development in Indonesia was played neatly by the saints and scholars, so that the accommodative nature of Islam could be easily accepted by the local community. One important culture is wayang, tradition that has been packaged in such a way by the saints that it can be used as a means of attracting the attention of local people to convert to Islam. ${ }^{10}$ Furthermore throughout the historical records mention that the spread of Islam in the Indonesian archipelago is through

\footnotetext{
${ }^{9}$ Ahmad Syafi'i Ma'arif, Islam dalam Bingkai Keindonesiaan dan Kemanusiaan: Sebuah Refleksi Sejarah (Bandung: Mizan, 2009), 55.

${ }^{10}$ Introduction to Prof. Dr. H. Ahmad Syafi'i Ma'arif "Sublimitas Indonesia" in Abdul Karim, Islam Nusantara: Pengaruh Keislaman dalam Sejarah Bangsa Indonesia (Yogyakarta: Reader Book Publisher, 2007), $\mathrm{X}$.
} 
trading. With a process we often call Penetration Pacifique (peacefully). It can also be said that the spread of Islam in Indonesia is not based on the mission or encouragement of power, but the spread of Islam is taking place slowly. ${ }^{11}$ The religion of Islam interacts with certain local cultures there is the possibility of Islam coloring, changing, processing, and actually renewing local culture, maybe Islam is also colored by local culture. Through this, the term localization process (Javanization) arises in which Islamic elements in Javanese cultural literature gave birth to Kejawen Islam. ${ }^{12}$ Interaction between Islam and local culture makes Javanese people adopt beliefs or rituals and traditions from other religions including HinduBuddhist traditions that are considered to be in line with their thinking. ${ }^{13}$ Even though they claim to be Islam, they also put Yasinan and Tahlilan when invited to slametan by their neighbors and relatives, attend recitation on Islamic holy days or Suro night to save the kris and other heirlooms and many more. This they do in order to find peace and calm in the face of tension due to the emergence of various kinds of life problems that never end. Thus consciously or not they are still applying HinduBuddhist culture in the teachings of Islam.

Various explanations above we can conclude that Islam Nusantara is more referring to how Islam interacts with local culture which should grow as part of national culture. Besides that the interaction that arises is not only a reflection of the flexibility of the Islam Nusantara in the spread of Islam in the homeland. Where Islamic preaching does not use a violent approach, but merges with local culture. But what needs to be underlined is that it does not contradict Islamic law.

\footnotetext{
${ }^{11}$ Koentjaraningrat, Pengantar Ilmu Antropologi (Jakarta: New Script, 1979), 260.

${ }^{12}$ Simuh, Islam dan Pergumulan Budaya Jawa (Bandung: Mizan Media Utama, 2003), 8.

${ }^{13}$ Ibid. 87.
} 
The Polemic of Islam Nusantara between Islamic Organizations: Nahdlatul Ulama and Hizbutahrir Indonesia

Dini Safitri has conducted research on "Rhetoric Debate in Islam Nusantara Discourse". ${ }^{14}$ The purpose of this study is to describe the "war" of rhetoric in Islam Nusantara. Islam Nusantara is a cultural assimilation that has occurred in Indonesia since Islam came to the archipelago. However, in texts produced on social media, there are many pros and cons regarding the practice of cultural assimilation with Islamic values. Text with each other to make arguments, so it's like being in a war to persuade readers. The author uses a qualitative methodology to analyze the rhetoric about text. The results showed that the war text occurred because of differences in perspective created by the Islamic organizational structure in Indonesia. The results of this study found before analyzing texts on the official website of NU and HTI. Researchers, trace the historical background of the establishment of these two Islamic community organizations. The following is a brief explanation of the history of NU and HTI. Starting from the history of NU. NU (Nahdlatul Ulama) was established on 16 Rajab 1344 H / 31 January 1926, in Surabaya, with KH. Hasyim Asy'ari as Rais Akbar. KH. Hasyim Asy'ari also formulated the basic principles of NU into two books, the Book of Qanun Asasi (basic principles), and the book I'tiqad Ahlussunnah Wal Jamaah. The essence of this book came to be known as the NU's khittah, which was used as a basis and reference for NU members, in thoughts and actions in the social, religious and political fields. There are three reasons behind the birth of NU: 1. Religious motives, 2. Nationalism motives, and 3. Motives to maintain the concept of Ahlussunnah wal Jama'ah. The religious motives behind the birth of NU are God's commands to uphold and defend religion in the archipelago, and to continue the struggle of Wali Songo. In addition, the Dutch-Portuguese not only

${ }^{14}$ Early Safitri. Debat Retorika dalam Wacana Islam Nusantara. Jakarta: Jakarta State Islamic University. 2016 
colonized the archipelago, but also spread Christianity-Catholicism very strongly. They brought Christian missionaries to various regions.

The motive for nationalism that underlies the birth of $\mathrm{NU}$, is a strong intention to unite clerics and religious leaders in the struggle against colonialism. The spirit of nationalism can also be seen from the name Nahdlatul Ulama, which means the Awakening of Ulama. KH. Hasyim Asy'ari as the first Rais, is known to be very nationalist. This is illustrated clearly when the NICA (Netherlands Indies Civil Administration) landed at Tanjung Perak on $25^{\text {th }}$ October 1945. Before NICA landed, on $23^{\text {rd }}$ October 1945, KH. Hasyim Asy'ari, on behalf of NU, stated the call or call for jihad fi sabilillah to all NU citizens, who later became known as the Jihad Resolution. There are three important points in the Jihad Resolution: a) First, every Muslim - even - old, young and poor, will fight the infidels who are hampering Indonesian independence. b) Second, fighters who die in the war of independence, deserve to be called martyrs. c) Third, Indonesian citizens who side with the invaders are considered to divide national unity and must be sentenced to death. The fatwa made Indonesian Muslims at that time obliged to defend the motherland. In fact, it is considered unlawful, if backed away when we are dealing with invaders within a radius of $94 \mathrm{~km}$ (the distance is adjusted to the ability of Qashar Prayers). The fatwa of Jihad, written in Pegon Arabic script and disseminated its appeal by Bung Tomo via RRI Surabaya radio. Hearing the call of jihad that was spread by Bung Tomo, the citizens of Surabaya and East Java were burning to fight against the invaders. Thousands of chaplains and students from various regions, came to Surabaya. The incident took place on November $10^{\text {th }}$, 1945, which was then commemorated as the heroic day for the Indonesian people. ${ }^{15}$ The clerics and warriors, formed a line of Sabilillah troops led by KH. Maskur. The students and youth formed the Hezbollah forces led by H. Zainul Arifin. While the elderly

${ }^{15}$ MC Ricklefs. A History of Modern Indonesia since c.1200. 4th Edition. (UK: Palgrave Macmillan, 2008). 
chaplains formed the Mujahideen led by KH. Wahab Hasbullah. This resistance bore fruit, namely the killing of the colonial leader, Brigadier General Mallaby. The motive for maintaining the concept of Ahlussunnah wal Jama'ah (Aswaja) which was the background for the birth of $\mathrm{NU}$, is to fortify Muslims, especially in Indonesia to remain loyal to the teachings of Islam Ahlussunnah wal Jama'ah, which means followers of the Sunnah of the Prophet, the Prophet's companions, and Salafus salih followers (followers of the Prophet-Companions), so as not to be tempted by new teachings that were not known at the time of the Apostles-Salafus Salih / teachings of Bid'ah experts. Meanwhile, at the NU's 27th Conference in 1984, the 1926 NU's khittah was rolled out, stating that NU's objectives referred to the lines, values, and NU's struggle model which was founded in 1926, when NU was founded. The foundation of NU's struggle in 1926 was as a religious social movement.

Meanwhile, the history of the entry of HTI (Hizb ut-Tahrir Indonesia), was estimated in the early 1980s. Starting from the mosque activist in the Al-Ghifari campus, IPB (Bogor Agricultural Institute), then formed a study to explore the idea of HTI. By the mid-1990s, HTI's ideas began to spread to various levels of society, both through the preaching of cadres in mosques, offices, factories, housing, and through the publication of books, Al-Islam bulletins, and Al-Wa'ie monthly magazines ie, which discusses specific themes, which serve as a reference in various discussion activities, seminars, and even demonstrations. ${ }^{16}$ When Indonesia entered the reform era, the event was a momentum for HTI to legalize its movement. In 2002, HTI, held the International Khilafah Islamiyah Conference in Senayan, Jakarta. The conference was attended by around 5,000 people. And since then, HTI has officially conducted its activities in Indonesia openly. HTI activities can be seen in public spaces, namely in the form of demonstrations, seminars (both on an international, national and local

\footnotetext{
${ }^{16}$ Kurniawan Abdullah. Gerakan Politik Islam Ekstraparlementer: Studi Kasus Hizbut Tahrír Indonesia. (Master Thesis, University of Indonesia, 2003)
} 
scale), public dialogue and discussion, and the proliferation of media in various regions in the country.

At the birth of HTI, it immediately declared itself as a political party with Islamic ideology, but refused to join the existing political system, because Indonesia still adheres to the political system created by infidels such as democracy and so on. HTI activities are political activities. They focus on community affairs in accordance with the law and its solution in Islam. In its political struggle, HTI loudly opposes imperialist infidels and seeks to liberate Indonesian Muslims from the shackles of foreign power, free people from foreign pressure and influence, and uproot the roots of foreign thought, culture, politics, economy, and military. ${ }^{17}$

After knowing the history, then searching the text on the official web is done. The search results show that the text of the war occurred because of different perspectives created by Islamic organizational structures in Indonesia. Based on JL Austin's speech act theory, namely locution, illocution and perlocution. There are 40 texts on the official website of $\mathrm{NU}$ which are used as research objects and 4 texts on the HTI official website. Of the 44 manuscripts, they all contain performative sentences. Referring to Austin, who divides performative sentences into five categories: 1). Verbal sentences (vindictive) sentences that state a decision or judgment, for example, "we declare the defendant guilty", 2). Exeritive sentences (exercitives), sentences that state the agreement, suggestions, warnings, and so on. For example, "we hope you agree with this decision", 3). Commissive sentences (commissives), are sentences marked with an agreement; for example, "we watch football tomorrow", 4). Behatitives (behatitives) are phrases related to social behavior because someone has had luck or misfortune, for example, "I congratulate you on your inauguration as an exemplary student", 5). Expositive sentences

${ }^{17}$ http://digilib.uinsby.ac.id/ Accessed August 20, 2018. 
(expositive) are treatment sentences that provide an explanation, information, or details to someone, for example, "I explained to you that he was innocent. Meanwhile, 44 of the texts also contained speech acts, making speech acts that contained three actions which took place in the same event, namely: 1) The locus speech act is a speech act that states something meaningful and understood. For example, "my teacher said that I must help him." 2) Illocutionary speech acts are speech acts that are usually identified with an explicit performative sentence, this is usually an illocutionary speech act related to licensing, thank you, sending, offering, and promises. For example, the teacher tells me to go ". 3). Perlokusi speech acts are speech acts relating to the speech acts of others in connection with the attitudes and behaviors of others who are nonlinguistic. For example, the doctor said to the patient, "Mother may suffer from coronary heart disease", then the patient will panic or be sad. The doctor's speech act is a speech act of percussion.

Islam Nusantara as the act of locution and perlocution speech from NU and HTI, has its own meaning. But the speech acts of NU and HTI perlocution require a long, long process, as spread in the text produced by NU. NU also realized that its efforts to be accepted also experienced a number of obstacles. Therefore, NU made rhetoric in various media to disseminate the ideas of Islam Nusantara. While HTI, feels it has an urgency to make rhetoric of the Islam Nusantara discourse, because there are elements of the Islam Nusantara discourse version of NU and Jokowi's governance practices, which are considered contrary to the context of HTI's struggle. Because of differences in values and interests of the Islam Nusantara discourse, there was a rhetorical debate about the Islam Nusantara discourse between NU and HTI in new media. Both organizations felt they had strong claims as arguments. The claim makes a speech act that is different because of differences in perspective in interpreting the Islam Nusantara rhetoric. 
Quantitative Analysis Results

Considering that the research carried out is (mixing methods), which is a method of analysis that combines qualitative and quantitative approaches, the explanation of each method used is explained below:

Descriptive Analysis

This section will explain the respondents' characteristics based on sex, age, occupation and income. Further in Table 1 below:

Table 1: Characteristics of Respondents

\begin{tabular}{|c|c|c|c|c|}
\hline No & $\begin{array}{c}\text { Characteristics of } \\
\text { Respondents }\end{array}$ & Category & amount & Percentage \\
\hline \multirow[t]{3}{*}{1} & \multirow[t]{2}{*}{ Gender } & Male & 187 & 93.50 \\
\hline & & Girl & 13 & 6.50 \\
\hline & Total & & 200 & 100.00 \\
\hline \multirow[t]{3}{*}{2} & \multirow[t]{3}{*}{ Age } & 20 years - 30 years & 21 & 10.50 \\
\hline & & 31 yrs - 41 yrs & 51 & 25.50 \\
\hline & & $\geq 42$ years old & 128 & 64.00 \\
\hline & Total & & 200 & 100.00 \\
\hline \multirow[t]{2}{*}{2} & \multirow[t]{2}{*}{ Occupation } & Civil servants & 38 & 19.00 \\
\hline & & Private & 162 & 81.00 \\
\hline
\end{tabular}




\begin{tabular}{|l|l|l|c|c|}
\hline \multirow{2}{*}{4} & Total & Income & $\mathbf{2 0 0}$ & $\mathbf{1 0 0 . 0 0}$ \\
\cline { 3 - 5 } & & $\begin{array}{l}\text { IDR } 1000000 \text { to } \\
2,000,000\end{array}$ & 105 & 52.50 \\
\cline { 3 - 5 } & & $\geq$ IDR 3,000,000 & 68 & 34.00 \\
\hline \multirow{2}{nnyyy}{} & Total & & 200 & $\mathbf{1 0 0 . 0}$ \\
\hline
\end{tabular}

Source: Research Results

Based on the data in Table 1 above, it is found that, the majority of respondents are male. Then the age range of most respondents is $\geq 42$ years. Furthermore, the occupations owned by respondents generally work in the private or entrepreneurial sector. While the income aspect, obtained a description that, they generally earn less than $1,000,000-2,000,000$.

\section{Quantitative Analysis}

There are three stages carried out in the quantitative analysis process in this study, including: (1) Testing the validity and reliability of research instruments. (2) Testing the spread of min and percentage of prejudices of religious leaders and community members about Islam Nusantara. Then the spread of min and percentage of social conflicts that occur in the midst of society. (3) Testing the research hypothesis.

Based on the results of the validity and reliability test using Cronbach alpha obtained reliability values of 0.817 (Prejudice) and 0.826 (social conflict) means that 
the reliability level of the instrument in the form of psychological scale is quite good and appropriate to use. This can be seen in Table 2 below:

Table 2: Measuring Instrument Reliability Tables

\begin{tabular}{|c|c|c|}
\hline Cronbach's Alpha & Cronbach's Alpha Based on Standardized Items & N of Items \\
\hline .817 & .783 & 200 \\
\hline .826 & .791 & 200 \\
\hline
\end{tabular}

Min and Percentage Spreads

This test is needed to see the tendency of the average distribution of prejudices of religious leaders and community members about Islam Nusantara. Then what about the spread of min and percentage of social conflicts that occur in the midst of society. This can be seen in Table 3 below:

Table 3: Min Spread and Percentage of Prejudice and Social Conflict

\begin{tabular}{|c|l|c|c|}
\hline Variable & Category & amount & Percentage \\
\hline Prejudice & High & 173 & 86.50 \\
\hline & Low & 27 & 13.50 \\
\hline Amount & & 200 & 100.00 \\
\hline Social conflict & High & 12 & 6.00 \\
\hline & Low & 188 & 94.00 \\
\hline
\end{tabular}




\begin{tabular}{|c|c|c|c|}
\hline Amount & & 200 & 100.00 \\
\hline
\end{tabular}

Source: Research Results

Based on Table 3 above, it is found that generally prejudice among religious leaders and community members is high 173 (86.5\%). Whereas social conflict in the community was classified as low, namely 188 (94\%). This means that the prejudices of community leaders and members of the community towards Islam Nusantara are high, where they assume that Islam Nusantara is primordial, anti-Arab, and even prejudiced as a new strategy from the Liberal, Western and Zionist Islamic Networks. However, religious leaders and community members generally assume that social conflict is relatively low, meaning that they do not want social conflict in the midst of society from differences in views about the Islam Nusantara. They do not want to be involved in empirical conflicts and will bring social upheaval which certainly will not benefit the social life of the people of the city of Padang, especially, then the people of West Sumatra in particular.

\section{Hypothesis test}

Furthermore, the results of testing the hypothesis obtained by the picture that there is no significant relationship between prejudice of religious leaders and community members with social conflicts that occur in the midst of society. This means that prejudice tends to be moderate to the contradiction between the pros and cons of Islam Nusantara. This can be seen in Table 4 below:

Table 4: Correlation Table between Prejudice and Social Conflict

\begin{tabular}{|l|r|r|r|}
\hline & & Prejudice & Social conflict \\
\hline Prejudice & Pearson Correlation & 1 &, $008(* *)$ \\
\hline
\end{tabular}




\begin{tabular}{|l|l|r|r|} 
& Sig. (2-tailed) & 200 &, 000 \\
Social conflict & Pearson Correlation &, $008(* *)$ & 200 \\
& Sig. (2-tailed) &, 000 & 1 \\
\hline & $\underline{\mathrm{N}}$ & $\underline{200}$ & $\underline{200}$ \\
\hline
\end{tabular}

** Correlation is significant at the 0.01 level (2-tailed).

Based on the analysis in Table 4 above, the picture is obtained that the Pearson correlation test (product moment) found the $r_{\text {count }}$ is 0 , 008. While the value of $r_{\text {table }}$ is 0.221 . So $r_{\text {count }}<r_{\text {table }}, \mathrm{H}_{0}=$ Rejected, meaning that there is no relationship between prejudice of religious leaders and community members with social conflicts about Islam Nusantara. This means that the two variables or variables, namely: Prejudice of religious leaders and members of the community with social conflicts each stand alone. Where even though prejudice that rejects or contradicts the Islamic Nusantara, does not give effect to social conflicts that occur in the midst of society.

This shows that the people of Padang City are not easily deceived and want to be physically involved in opposing views about Islam Nusantara. Society is rational and egalitarian and tends to be pragmatic in assessing the value of social problems. Prejudice does not give birth to social conflict, but is considered as a different point of view that needs to be respected from the rules of nation and state. Egalitarian in a context where religious leaders are only a symbol of power from Islamic institutions legally recognized (such as the Indonesian Ulama Council) which needs to be respected. But the community has its own independent logic and is not easily intervened by formal religious institutions. Pragmatic here lies in the 
fact that social conflict, even if considered a wise step in favor of religious authority holders, does not assume that this is a solution that benefits the community. Even social conflict has only a counterproductive impact on social life.

\section{Conclusion}

Islam Nusantara is a reflection of local wisdom that grows and develops. Where Islam Nusantara was born and grew and developed in Indonesia, along with the historical development of the Islamic civilization that accompanied it. Historical facts illustrate that the Islam Nusantara is not a new Islamic teaching or ideology that has become a separate sect in various societies in Indonesia. However, Islam Nusantara is a form of diversity of Islamic practices that are in touch with the traditions and cultural values that exist in society.

Islam Nusantara is a form of development of Islam that is moderate and full of tolerance, as noble values which are held in high esteem by the ancestors of this beloved country. Islam in Banda Aceh, for example, has unique characteristics with distinct characteristics that are different in other regions. While Islam in the land of Java is also a local-style Islam with a bandage of local culture, which distinguishes it from Islam in other regions in Indonesia. For example: a tomb of an Islamic figures who was buried in a temple (a place of worship of the Chinese people). Because the tomb is the tomb of an Islamic figure, the tomb is often visited by people for pilgrimage.

\section{Recommendation}

What we want to underline in this research are: (1) History proves the development of Islam in the archipelago in line with the growth and development of Islam and local cultural values that exist in the midst of society. Islam Nusantara as a 
form of local wisdom is never clashed with social values and norms that grow in the midst of society. (2) The Islam Nusantara in Padang should be socially accepted. This is proven by the customary philosophy of the Minang community based on "Adaik Basandi Syarak, Syarak Basandi Kitabullah" (AS-SBK), namely: Customs based on Sharia and Sharia based on the Qur'an. This fact proves that Islam and culture are synergized with one another, supporting patterns of behavior and values and cultural norms of the people of Padang that embody the view of the Islam Nusantara. (3) Then the different perspectives of religious leaders who support or reject Islam Nusantara from community members about Islam Nusantara in the city of Padang. But to maintain the order of the life of Padang people there is no social conflict in the middle of the community, this is caused by the thought of Padang people that the majority of Minang are rational, egalitarian, and pragmatic.

\section{Appreciation}

The research team gave a great appreciation to the Ministry of Religion Affair of the Republic of Indonesia for funding this research, with the support of these funds the implementation of the research could be carried out. Then the informants and respondents involved in the research. We also need to express our high appreciation to the 3rd International Workshop and Training Methodology Training Archipelago of Islam Nusantara and the University of Yudhastra, Pasuruan and LTN-NU East Java which facilitated the holding of activities and published our articles in the event.

\section{References}

Allen, James. 2007. "Aristotle on the Disciplihnes of Argument: Rhetoric, Dialectic, Analytic" In Rhetorica 25: 87-108. 
Al-Mustofa, Abdullah. 2015. The "Islamic Archipelago" Religious Declaration. Written June 8, 2015, http://www.hidayatullah.com/ Accessed August 11, 2018.

Al-Saggaf, Yeslam and Peter Simmons. 2015. Social media in Saudi Arabia: Exploring its use during two natural disasters. Technological Forecasting and Social Change Vol 95

Brummet, Barry. 2015. Rhetoric in Popular Culture, Fourth Edition. UK: Sage Publication Ltd.

Cummings, Louise. 2007. Pragmatics, A Multidisciplinary Perspective. Yogyakarta: Student Library

D, Ruben Brent and Lea P Stewart. 2006. Communication and Human Behavior. United States: Allyn and Bacon

Denzin, N. and Lincoln, Y. Eds. 2011. Handbook of qualitative research, 4th ed. Thousand Oaks, CA: Sage.

Djurai, Dhimam Abror. 2015. Debate on the Islamic Archipelago Attributes in the style of Jokowi. Written June 21, 2015. http://www.jpnn.com/ Accessed August 12, 2018.

Faisal Haji Othman, Islam Hadhari: The Problem of Asking for the Paradigm of Islamic Thought. (Kuala Lumpur: Ministry of Information, 2004).

http://digilib.uinsby.ac.id / Accessed August 4, 2018.

http://hizbut-tahrir.or.id/ Accessed August 12, 2018.

http://hizbut-tahrir.or.id/ Accessed August 14, 2018.

http://hizbut-tahrir.or.id/ Accessed August 15, 2018.

http://hizbut-tahrir.or.id/ Accessed August 2, 2018.

http://www.nu.or.id/ Accessed August 10, 2018.

http://www.nu.or.id/ Accessed August 12, 2018.

http://www.nu.or.id/ Accessed August 8, 2018.

http://www.nu.or.id/ Accessed August 9, 2018.

https://www.researchgate.net/ Accessed August 12, 2018.

Islam Hadhari: Concept and Prospect |PDF request. Available from: https://www.researchgate.net/ [accessed Aug 24 2018]. 
Kurniawan Abdullah.2003. Extraparlementary Islamic Political Movement: Case Study of Hizb ut-Tahrír Indonesia. UI Thesis

Lunsford, Andrea A, Kirt H. Wilson and R. Eberly (eds.) 2009. The SAGE Handbook of Rhetorical Studies. UK: Sage Publication Ltd.

M. Periasamy. Islam Hadhari: Prospect from a Non-Muslim Perspective. (Kuala Lumpur: Ministry of Information, 2004).

Naupal. 2014. The Reconstruction of The Role Of Islam In Indonesia As A Propethic Religion. Al-Ulum Volume 14 N0. 2, December 2014, Page 259-274

New Straits Times. Interview with Minster in the Prime Minister's Department (Religious Affairs) Datuk Prof. Dr. Abdullah Md. Zin, Kuala Lumpur, August 10, 2004.

Office of the Prime Minister of Malaysia, Web site: http://www.pmo.gov.my/ Accessed August 12, 2018.

Office of the Prime Minister of Malaysia, Web site: http://www.pmo.gov.my/ Accessed August 22, 2018.

Office of the Prime Minister of Malaysia, Website: http://www.pmo.gov.my/ Accessed August 12, 2018.

Ricklefs, MC. 2008. A History of Modern Indonesia since c.1200.4th Edition. UK: Palgrave Macmillan

Romzek, Barbara S. 2015. Living Accountability: Hot Rhetoric, Cool Theory, and Uneven Practice. in Political Science \& Politics, Volume 48, Issue 01, January 2015, pp 27-34. American Political Science Association.

Speech by prime minister of Malaysia on occasion of the conference of the honorary degree of doctorate of law by the International Islamic University in Islamabad, Pakistan, February 17, 2005.

Speech by prime minister of Malaysia on occasion of the conference of the honorary degree of doctorate of law by the International Islamic University in Islamabad, Pakistan, February 17, 2005.

Speech by Prime Minister of Malaysia, Abdullah Ahmad Badawi, UMNO Supreme Council, Kuala Lumpur, September 23, 2004.

Speech by Prime Minister of Malaysia, Abdullah Ahmad Badawi, UMNO Supreme Council, Kuala Lumpur, September 23, 2004. 
Jurnal Hunafa: Studia Islamika, Volume 16, Number 2, p. 1- 150

E-ISSN: 2355-7710

P-ISSN: 1411-125X

Zainal Abidin Bin Abdul Kadir, Islam Hadhari in Malaysia, (Kuala Lumpur: Ministry of Information, 2004).

Zainal Abidin Bin Abdul Kadir, Islam Hadhari in Malaysia, (Kuala Lumpur: Ministry of Information, 2004). 